\title{
Abnormalities of cerebrospinal fluid amino-acids in purulent meningitis
}

\author{
R. N. COR T O N, E. H.F. M c G A LE, C. S T O N IER, \\ E. C. HUT CH I NSON, A N G . M. A B E R \\ From the Departments of Neurology and Nephrology, Medical Research Unit, \\ North Staffordshire Hospital Centre, Stoke-on-Trent, Staffordshire
}

SUMMARY Serial measurements were made of the cerebrospinal fluid and plasma amino-acid concentrations in 12 patients with purulent meningitis. Marked increases in the concentrations of most CSF amino-acids were found, possibly caused by altered transport mechanisms in the inflamed meninges and choroid plexuses.

In health, the amino-acid composition of the cerebrospinal fluid is relatively stable at a level markedly lower than that found in plasma (McGale et al., 1977). In disease, alterations in the CSF amino-acid composition have been described in steady state chronic renal failure (Pye et al., 1979), in patients undergoing haemodialysis (McGale et al., 1979) and in association with neurological disorders including epilepsy (Mutain et al., 1974), Parkinsonism (Lakke and Teelken, 1976), and Huntington's chorea (Perry et al., 1973). There is, however, relatively little information about the CSF amino-acid composition in meningitis, a disease in which the blood-CSF barrier to electrolytes and protein is known to change (Nobecourt and Voisin, 1903; Cohen, 1927; Kabat et al., 1942; Tubiana et al., 1951; Rossi and Schneider, 1953; Taylor et al., 1954; Bradbury et al., 1963; Sambrook, 1974).

The present investigation was, therefore, designed to study changes that might occur in the CSF of patients with purulent meningitis. The findings demonstrate marked increases in CSF amino-acid concentrations.

\section{Patients and methods}

Twelve patients with purulent meningitis were studied (Table 1). The diagnosis of meningitis was confirmed by microscopy, culture, and chemical analysis of the lumbar CSF on ad-

Address for correspondence and reprint requests: Dr E. H. F. McGale, Medical Research Unit, North Staffordshire Medical Institute, Hartshill, Stoke-on-Trent, Staffordshire ST4 7NY.

Accepted 26 March 1979 mission to hospital. Subsequent examination of the CSF was carried out on the basis of clinical and therapeutic considerations. All specimens, except those taken on hospital admission, were collected after a fast of 12-18 hours. Since the precise time of invasion of the central nervous system by the organism is difficult to determine exactly, the first clinical symptoms-for example, headache, vomiting, impairment of consciousness-were taken as the starting point of the disease. Antibiotics used included penicillin, sulphonamides, chloramphenicol, gentamycin, and colistin. On the basis of serial determination of CSF amino-acid concentrations before, during, and after use of these antibiotics, it seems unlikely that they influence the CSF amino-acid profile.

Specimens of lumbar CSF and venous blood were collected simultaneously. After centrifugation $\left(4000 \mathrm{~g}, 10 \mathrm{~min}, 4^{\circ} \mathrm{C}\right)$, specimens were deproteinised, stored, and analysed for their free amino-acid content as described previously (McGale et al., 1977). Glutamine and glutamic acid concentrations were measured on an aliquot of the same specimens by an enzymatic procedure (Pye et al., 1978). An aliquot of CSF was cultured and examined by microscopy. Quantitative measurement of protein and sugar concentrations, and differential white cell count were carried out using standard laboratory procedures.

For statistical comparison of the pattern of amino-acid change in the CSF, the results were divided into four periods. Period 1 contained all values for CSF amino-acid concentration before reaching maximum concentration. This period varied from $0-4$ days (mean 2.2 days). Period 2 
Table 1 Details of patients studied and laboratory investigations on the initial CSF specimen

\begin{tabular}{|c|c|c|c|c|c|c|c|}
\hline \multirow[t]{2}{*}{ Patient } & \multirow[t]{2}{*}{$\operatorname{Sex}$} & \multirow[t]{2}{*}{$\begin{array}{l}\text { Age } \\
(y r)\end{array}$} & \multirow[t]{2}{*}{ Organism } & \multicolumn{2}{|c|}{$\begin{array}{l}\text { White cell count } \\
\left(\text { per } \mathrm{mm}^{3}\right)\end{array}$} & \multirow[t]{2}{*}{$\begin{array}{l}\text { Protein } \\
(\mathrm{g} / l)\end{array}$} & \multirow[t]{2}{*}{$\begin{array}{l}\text { Glucose } \\
\text { (mmolll) }\end{array}$} \\
\hline & & & & Polymorphs & Lymphocytes & & \\
\hline EA & $\mathbf{M}$ & 52 & Pneumococcus & 4752 & 48 & 2.0 & 0.0 \\
\hline CD & $\mathbf{M}$ & 65 & Pneumococcus & 3500 & 0 & 4.5 & 0.7 \\
\hline DD & $\mathbf{M}$ & 12 & Pneumococcus & 4680 & 520 & 7.1 & 0.4 \\
\hline TF & $\mathbf{M}$ & 15 & Pneumococcus & 1900 & 100 & 4.0 & 0.0 \\
\hline MK & $\mathbf{F}$ & 77 & Pneumococcus & 172 & 19 & 7.0 & 0.0 \\
\hline DR & $\mathbf{M}$ & 32 & Pneumococcus & 5940 & 60 & 8.0 & 0.0 \\
\hline BD & $\mathbf{F}$ & 42 & Meningococcus & 2520 & 280 & 5.0 & 0.0 \\
\hline PE & $\mathbf{F}$ & 48 & Meningococcus & 1500 & 0 & 2.4 & 0.5 \\
\hline CF & $\mathbf{F}$ & 27 & Meningococcus & 5290 & 110 & 4.0 & 0.0 \\
\hline JW & $\mathbf{M}$ & 75 & Meningococcus & 8000 & 0 & 0.9 & 0.0 \\
\hline SB & $\mathbf{M}$ & 72 & Streptococcus type D & 1900 & 100 & 3.2 & 0.5 \\
\hline JB & $\mathbf{M}$ & 75 & Pseudomonas aeruginosa & 1800 & 200 & 1.6 & 2.0 \\
\hline
\end{tabular}

contained an analysis of data for the maximum CSF amino-acid concentration noted in each patient. This period varied from 3-6 days (mean 4.0 days). Period 3 contained all values after the maximum CSF amino-acid concentration until day 15 of illness (mean 8.0 days). Period 4 contained all values between days 16 and 60 of illness (mean 30.0 days).

Values for CSF protein concentrations and white cell counts and plasma amino-acid concentrations were grouped into the same time intervals.

Mean and standard deviations of data within each time group were determined using a HewlettPackard 97 calculator. Results were compared with our normal values (McGale et al., 1977) using the Wilcoxon rank sum test. Correlation of CSF and plasma amino-acid concentrations was made by calculation of the linear (productmoment) correlation coefficient.

\section{Results}

CEREBROSPINAL FLUID

Serial measurements of the mean total CSF aminoacid concentration are shown in the Figure, and data for individual CSF amino-acid and protein concentrations and white cell counts in Table 2 . The mean total CSF amino-acid concentration was increased significantly above normal throughout the period of study irrespective of the infecting organism, at maximum between the third and sixth days of the illness (mean: 4 days). The mean maximum value was $3637 \mu \mathrm{mol} / 1$ ( \pm 840 SD) compared with a value of $826 \mu \mathrm{mol} / 1$ ( $\pm 102 \mathrm{SD})$ in normal subjects $(P<0.001)$. Thereafter there was a gradual decrease towards the normal concentration (Figure).

The serial data for individual amino-acids showed that the concentrations of 24 were significantly increased (Table 2). Four of these amino- acids (aspartic acid, proline, cystine, and 3methylhistidine) are present in normal CSF in trace quantities only. In contrast, the concentrations of nine CSF amino-acids were not significantly different from normal. In addition to glutamic acid and phosphoethanolamine (Table 2 ), the CSF concentration of seven other aminoacids present in trace quantities in normal individuals (hydroxyproline, sarcosine, 2-aminoadipic acid, cystathionine, $\gamma$-aminobutyric acid 1-methylhistidine, and tryptophan) were not significantly increased.

PLASMA

Data for plasma amino-acid concentrations are shown in Table 3. Although the mean total plasmas amino-acid concentration was significantly rec duced (mean $2555 \mu \mathrm{mol} / 1 \pm 624, \mathrm{P}<0.01$ ) in the early phase of illness (0-4 days, mean 2.2 days) when compared with normal (mean $3556 \mu \mathrm{mol} / 1$ $\pm 904 \mathrm{SD}$ ), at all subsequent times the total plasma amino-acid concentration did not differ significantly from normal $(\mathrm{P}>0.05)$.

Data for individual amino-acids show that the concentrations of only four (ornithine, cystine, aspartic acid, and phenylalanine) were significantly increased at any time of the illness $(\mathrm{P}<0.001-0.02)$.

\section{CSF WHITE CELL COUNT}

Significant increases in the total white cell count in the CSF were present in all patients. Maximum values occurred in the early phase of the illness with a mean value of 3402 cells per $\mathrm{mm}^{3}$ (range 191-8000 cells per $\mathrm{mm}^{3}$ ) as shown in the Figure. This antedated the maximal elevation of the mean total CSF amino-acid concentration by a mean of 1.7 days (range $0-3$ days). Thereafter the total white cell count fell progressively towards normal. When CSF polymorphonuclear leucocyte and lymphocyte counts were examined separately, the 

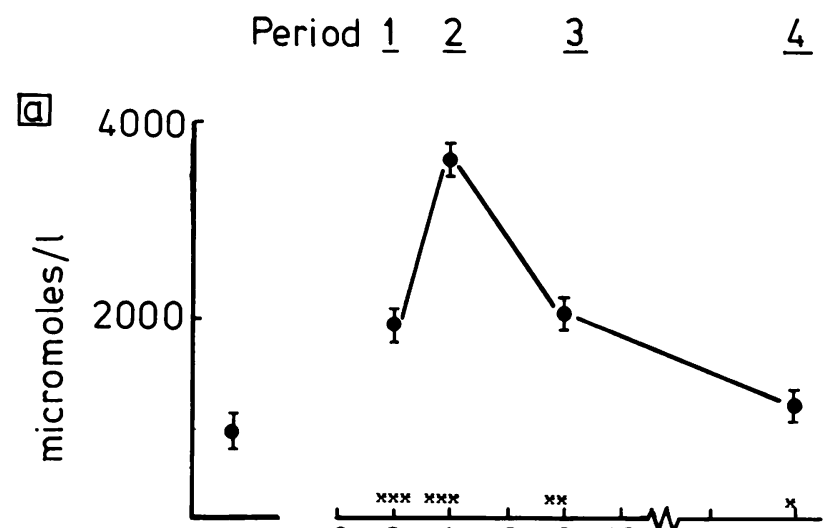

b

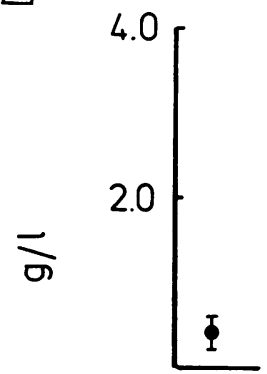

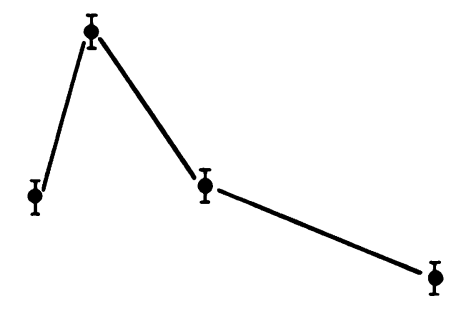

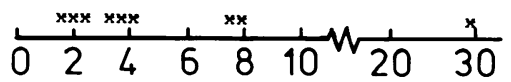

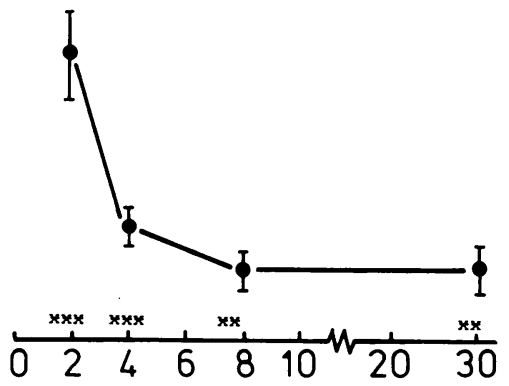

C]

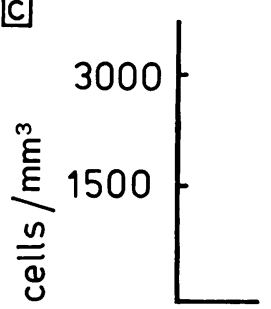

Figure Comparison of serial changes in (a) amino-acid concentration, (b) protein, and (c) cell count in CSF in patients with purulent meningitis with normal values. All values are mean $\pm S E M$ for the four time periods defined in text. $\mathrm{xxx}=P<0.001$ $\mathrm{xx}=\boldsymbol{P}<0.01 \mathrm{x}=\boldsymbol{P}<0.02$.

pattern of change was similar to that of the total CSF white cell count, the highest count being found in the first specimen examined and falling subsequently towards normal.

\section{CSF PROTEIN CONCENTRATION}

Significant increases in the CSF protein concentration were present in all patients, with a maximal mean value of $3.3 \mathrm{~g} / 1$ (range $0.5-8 \mathrm{~g} / \mathrm{l}$ ) occurring in the early phase of the illness. This antedated the mean total CSF amino-acid concentration by a mean of 2.2 days (range 1-3 days).
Subsequently there was a progressive fall towards normal (Figure).

\section{BACTERIOLOGICAL STUDIES OF THE CSF}

Bacteria were cultured in the CSF in all patients at the time of the initial lumbar puncture. The infecting organism varied from patient to patient (Table 1). Treatment resulted in an elimination of organisms in all but one patient (JB, Table 1) well in advance of the attainment of maximum CSE amino-acid concentration (mean 4.0 days), and indeed the total CSF amino-acid concentration 
Table 2 Comparison of CSF amino-acids and protein concentrations and white cell counts in normal individuals and patients with purulent meningitis. All values are $\mu$ mol/l (mean士SD). For explanation of time periods, see text. For all values in purulent meningitis compared with normal, $P<0.01$ unless otherwise indicated

\begin{tabular}{|c|c|c|c|c|c|c|c|c|c|c|}
\hline \multirow[t]{2}{*}{ Amino-acid } & \multicolumn{2}{|c|}{$\begin{array}{l}\text { Normal values } \\
\text { (McGale et al. } 1977)\end{array}$} & \multicolumn{8}{|c|}{ Purulent meningitis } \\
\hline & \multicolumn{2}{|c|}{$(N=37)$} & \multicolumn{2}{|c|}{$\begin{array}{l}\text { Period } 1 \\
0-4 \text { days } \\
(\text { mean 2.2) } \\
(N=11)\end{array}$} & \multicolumn{2}{|c|}{$\begin{array}{l}\text { Period } 2 \\
\text { maximum 3-6 days } \\
(\text { mean } 4.0) \\
(N=9)\end{array}$} & \multicolumn{2}{|c|}{$\begin{array}{l}\text { Period } 3 \\
4-15 \text { days } \\
(\text { mean } 8.2) \\
(N=7)\end{array}$} & \multicolumn{2}{|c|}{$\begin{array}{l}\text { Period } 4 \\
16-60 \text { days } \\
(\text { mean } 30.7) \\
(N=6)\end{array}$} \\
\hline Phosphoserine & 4.2 & 1.7 & 6.5 & 2.5 & 8.5 & 3.1 & 5.7 & 1.9 & 3.6 & 2.4 \\
\hline Taurine & 7.6 & 2.1 & 45.2 & 32.0 & 56.6 & 32.1 & 24.4 & 24.5 & 12.8 & 8.1 \\
\hline Phosphoethanolamine & 5.4 & 2.3 & 4.5 & $3.6^{*}$ & 9.0 & $5.4^{*}$ & 7.0 & $2.8^{*}$ & 3.8 & $1.6 \dagger$ \\
\hline Aspartic acid & - & - & 6.8 & 5.1 & 9.3 & 4.9 & 4.6 & 2.8 & 3.3 & 3.0 \\
\hline Hydroxyproline & - & - & - & - & - & 一 & - & - & - & - \\
\hline Threonine & 35.5 & 8.9 & 69.1 & $60.0 \dagger$ & 206.6 & 97.7 & 114.9 & 80.3 & 40.3 & $34.0^{*}$ \\
\hline Serine & 29.5 & 6.5 & 32.9 & 34.8 & 95.6 & 48.4 & 52.5 & 34.0 & 22.1 & 16.5 \\
\hline Asparagine & 13.5 & 4.6 & 155.3 & 113.5 & 376.2 & 319.4 & 135.3 & 93.0 & 40.9 & 23.1 \\
\hline Glutamic acid & 26.1 & 18.9 & 19.7 & $13.7^{*}$ & 11.7 & 8.2* & $22.2 *$ & $16.0^{*}$ & $18 \cdot 1$ & $23.8^{*}$ \\
\hline Glutamine & 552.0 & 79.0 & 891.0 & 46.3 & 1416.9 & 337.6 & 1022.0 & 385.0 & 611.0 & 128.0 \\
\hline Proline & - & - & 66.7 & 67.6 & 116.2 & 99.9 & 63.8 & 76.6 & 15.9 & 20.0 \\
\hline Glycine & 5.9 & 1.8 & 87.5 & 82.3 & 186.9 & 91.3 & 96.6 & 83.1 & 36.1 & 33.6 \\
\hline Alanine + citrulline & 34.3 & 8.2 & 158.1 & 125.7 & 252.5 & 181.4 & 167.3 & 134.8 & 103.9 & 63.4 \\
\hline 2-Aminobutyric acid & 3.5 & 1.4 & 21.8 & 21.0 & 32.5 & 14.3 & 18.8 & 12.5 & 12.0 & $14.8 *$ \\
\hline Valine & 19.9 & 4.1 & 126.8 & 95.0 & 218.0 & 73.8 & 103.6 & 77.0 & 42.7 & 37.7 \\
\hline Cystine & - & - & 12.5 & 10.5 & 23.0 & 15.0 & 10.9 & 10.8 & 3.4 & 2.1 \\
\hline Methionine & 2.5 & 0.9 & 25.4 & 21.7 & 48.5 & 22.5 & 21.5 & 19.2 & 5.6 & 4.1 \\
\hline Isoleucine & 6.2 & 1.4 & 47.7 & 42.6 & 97.4 & 41.8 & 39.1 & 33.2 & 12.0 & $9.3^{*}$ \\
\hline Leucine & 14.8 & 3.9 & 87.6 & 68.2 & 168.7 & 56.7 & 69.1 & 52.0 & 24.4 & $23.3^{*}$ \\
\hline Tyrosine & 9.5 & 2.6 & 60.5 & 45.4 & 113.1 & 44.6 & 49.6 & 37.0 & 16.4 & $14.0^{*}$ \\
\hline Phenylalanine & 9.9 & 2.0 & 92.4 & 64.4 & 135.6 & 60.1 & 56.8 & 47.5 & 16.0 & $12.5 \dagger$ \\
\hline Ornithine & 3.8 & 0.9 & 25.7 & 20.3 & 32.7 & 15.0 & 14.4 & 12.0 & 7.5 & 2.5 \\
\hline Lysine & 20.8 & 4.0 & 115.9 & 95.5 & 201.0 & 86.3 & 92.1 & 70.4 & 36.1 & 22.1 \\
\hline Histidine & 12.3 & 2.2 & 49.7 & 33.7 & 29.3 & 31.4 & 35.9 & 26.7 & 14.2 & $7.3^{*}$ \\
\hline 3-Methylhistidine & - & - & 5.4 & 6.6 & 10.9 & 8.2 & 6.3 & 6.4 & 1.8 & 0.9 \\
\hline Arginine & 22.4 & 4.2 & 63.0 & 57.5 & 129.9 & 53.2 & 61.2 & 45.2 & 29.8 & $12.5^{*}$ \\
\hline Total & 826.0 & 102.0 & 1969.0 & 1119.0 & 3637.0 & 844.0 & 2143.0 & 1017.0 & 1135.0 & 461.0 \\
\hline Protein $(\mathrm{g} / \mathrm{l})$ & 0.29 & 0.03 & 3.3 & 2.0 & 1.3 & 0.5 & 0.8 & 0.3 & 0.8 & 0.7 \\
\hline White cells (per $\mathrm{mm}^{3}$ ) & - & - & 3402.0 & 2394.0 & 1287.0 & 1189.0 & 139.0 & 156.0 & 40.0 & 25.0 \\
\hline
\end{tabular}

*not significant $(P>0.05)$

$+0.05>P>0.01$

remained raised many days after the lumbar CSF remained sterile.

\section{Discussion}

There is a marked increase in the concentration of most CSF amino-acids in purulent meningitis, irrespective of the causative organism. Although the time of maximum abnormality involving the total CSF amino-acid concentration varied, the mean maximum increase, detected on the fourth day, was approximately four and a half times the normal mean concentration. This increase in total CSF amino-acid concentration results from an increase of the concentration of 24 individual amino-acids. These findings are at variance with those of Buryakova and Sytynsky (1975) who, using paper chromatography for amino-acid separation and quantitation, found increased CSF concentrations of glutamic acid, glutamine, and $\gamma$-aminobutyric acid (GABA) only. Since the present study used a double enzymatic procedure and automatic ion-exchange chromatography, this variance may, therefore, result from methodological differences. The absence of a significant change in the CSF glutamic acid concentration in the present study is of particular interest in view of the marked increase noted for CSF glutamine concentration. Both these amino-acids are major components of brain tissue (Perry et al., 1971), and the differences in behaviour of these two metabolically related substances might be explained by the high capacity of cerebral tissue for glutamic acid uptake (Stern et al., 1949).

Our findings suggest that changes in plasma amino-acid concentrations are unlikely to account for the abnormal CSF pattern, since no simultaneous increase in total plasma amino-acid concentration was found. Indeed, at the time of maximum increase in CSF amino-acid concentration, the concentrations of many individual plasma amino-acids were significantly reduced.

The extent to which metabolism and destruction of white cells or bacteria contributes to the changes in CSF amino-acid concentration is 
Table 3 Serial venous amino-acid concentrations in normal individuals and in patients with purulent meningitis. All values are $\mu \mathrm{mol} / \mathrm{l}$ (mean $\pm S D$ ). For explanation of time periods, see text

\begin{tabular}{|c|c|c|c|c|c|c|c|c|c|c|}
\hline \multirow[t]{2}{*}{ Amino-acid } & \multicolumn{2}{|c|}{$\begin{array}{l}\text { Normal values } \\
\text { (McGale et al. 1977) }\end{array}$} & \multicolumn{8}{|c|}{ Purulent meningitis } \\
\hline & & & \multicolumn{2}{|c|}{$\begin{array}{l}\text { Period } 1 \\
0-4 \text { days } \\
(\text { mean 2.2) } \\
(N=11)\end{array}$} & \multicolumn{2}{|c|}{$\begin{array}{l}\text { Period } 2 \\
\text { maximum } 3-6 \text { days } \\
(\text { mean } 4.0) \\
(N=9)\end{array}$} & \multicolumn{2}{|c|}{$\begin{array}{l}\text { Period } 3 \\
4-15 \text { days } \\
(\text { mean } 8.2) \\
(N=7)\end{array}$} & \multicolumn{2}{|c|}{$\begin{array}{l}\text { Period } 4 \\
16-60 \text { days } \\
(\text { mean } 30.7) \\
(N=6)\end{array}$} \\
\hline Phosphoserine & 8.3 & 5.7 & 3.8 & $3.4 \ddagger$ & 4.1 & $2.5 \dagger$ & 4.0 & $3.8+$ & 3.0 & $0.9+$ \\
\hline Taurine & 77.2 & 26.1 & 18.4 & $24.9^{+}$ & 85.4 & 25.3 & 87.5 & 31.4 & 90.8 & 31.8 \\
\hline Phosphoethanolamine & 5.1 & 5.3 & 3.9 & $3.5 \ddagger$ & 5.0 & $2.9 \ddagger$ & 7.1 & $7.6 \ddagger$ & 1.7 & $1.1 *$ \\
\hline Aspartic acid & - & - & 7.5 & $4.7 \ddagger$ & 10.7 & $4.9 \ddagger$ & 9.8 & $3.5 \ddagger$ & 5.0 & $2.6^{*}$ \\
\hline Hydroxyproline & - & - & 14.8 & $8.0^{+}$ & - & - & - & - & 14.5 & 9.2 \\
\hline Threonine & $\overline{165.5}$ & 61.4 & 107.8 & $51.7 \ddagger$ & 151.5 & 37.2 & 158.5 & 53.4 & 97.4 & $23.4+$ \\
\hline Serine & 139.7 & 51.6 & 85.6 & $33.1 \ddagger$ & 114.7 & 28.7 & 119.9 & 24.7 & 89.7 & $16.0 \ddagger$ \\
\hline Asparagine & 111.7 & 52.1 & 137.3 & $103.2^{+}$ & 153.7 & 88.6 & 127.6 & 73.7 & 81.0 & 38.4 \\
\hline Glutamic acid & 61.3 & 30.8 & 55.6 & 37.5 & 69.8 & 57.9 & 69.3 & 31.0 & 58.9 & 25.9 \\
\hline Glutamine & 641.0 & 93.0 & 503.8 & $215.1 \ddagger$ & 544.4 & 151.6 & 610.7 & 111.8 & 577.0 & $97.9^{*}$ \\
\hline Proline & 323.7 & 256.0 & 112.4 & $43.3+$ & 147.0 & $32.9 \ddagger$ & 172.4 & $66.1 \ddagger$ & 168.6 & $75.4 \ddagger$ \\
\hline Glycine & 282.7 & 101.6 & 160.3 & $48.3_{+}^{+}$ & 211.1 & 51.8 & 233.4 & 50.8 & 286.3 & 221.4 \\
\hline Alanine + citrulline & 488.5 & 192.1 & 309.6 & $111.5 \ddagger$ & 321.9 & $123.2 \ddagger$ & 372.8 & 135.1 & 376.9 & 131.7 \\
\hline 2-Aminobutyric acid & 29.8 & 12.2 & 28.2 & 13.7 & 35.5 & 20.5 & 25.8 & 9.1 & 14.4 & $5.6 \ddagger$ \\
\hline Valine & 308.6 & 116.0 & 211.9 & $55.0 \pm$ & 233.2 & 59.4 & 209.8 & $28.5 \ddagger$ & 205.0 & $32.7 \ddagger$ \\
\hline Cystine & 123.7 & 50.0 & 83.0 & $33.8 \pm$ & 107.3 & 24.9 & 100.4 & $27.9^{+}$ & 114.7 & $50.9^{+}$ \\
\hline Methionine & 27.7 & 11.7 & 25.5 & $10.0^{+}$ & 35.1 & 12.6 & 29.8 & 9.6 & 17.0 & $4.8 \ddagger$ \\
\hline Isoleucine & 76.7 & 29.8 & 58.4 & 17.9 & 72.4 & 25.4 & 71.3 & 14.7 & 65.1 & $20.5^{+}$ \\
\hline Leucine & 155.3 & 58.6 & 122.6 & 32.5 & 144.4 & 40.7 & 131.2 & 20.8 & 110.8 & $17.9 \dagger$ \\
\hline Tyrosine & 73.0 & 26.3 & 60.8 & 15.2 & 78.0 & 21.6 & 72.4 & 20.5 & 59.6 & 13.8 \\
\hline Phenylalanine & 64.0 & 24.2 & $\begin{array}{r}005.6 \\
105.6\end{array}$ & $31.0 \ddagger$ & 97.0 & $26.4 \ddagger$ & 75.2 & 25.1 & 51.1 & 11.3 \\
\hline Ornithine & 73.5 & 25.8 & 66.6 & $19.7^{+}$ & 93.1 & $17.1 t^{+}$ & 91.2 & 34.7 & 90.7 & 25.8 \\
\hline Lysine & 180.7 & 64.2 & 139.6 & 49.2 & 212.5 & $59.1 \ddagger$ & 229.3 & 66.5 & 175.4 & 29.7 \\
\hline Histidine & 79.8 & 23.1 & 49.3 & $11.8 \ddagger$ & 59.4 & $17.1 \ddagger$ & 59.0 & $16.4^{*}$ & 53.4 & 6.6 \\
\hline Arginine & 80.9 & 28.3 & 63.7 & 37.6 & 87.4 & $24.1^{+}$ & 99.9 & 35.2 & 75.7 & 14.2 \\
\hline Total & 3556.0 & 904.0 & 2555.0 & 624.0 & 2944.0 & 513.0 & 3165.0 & 518.0 & 2957.9 & 295.7 \\
\hline Protein & 74.3 & 11.9 & & & & & & & & \\
\hline
\end{tabular}

$* 0.5>\mathrm{P}>0.02$.

$+0.02>P>0.01$.

$\ddagger \mathrm{P}<0.01$.

All other values not significant $(P>0.05)$.

unclear. The absence of a clear temporal correlation between CSF amino-acid concentration and white cell count suggests that white cells are not a major contributory factor. Preliminary in vitro experiments designed to study the release of amino-acids from white cells into CSF support this view. Likewise, since bacteria are only detected in the CSF in the early stages of the disease, it seems unlikely that they make a major contribution to the abnormal amino-acid pattern found in the present study. Additional support for a minor role of white cells and bacteria comes from the observation that these tissues contain only low free amino-acid concentrations (Holden, 1961; Houpert et al., 1976).

The possibility that the increase in CSF aminoacid concentration might result, at least in part, from amino-acid release from damaged nervous tissue receives some support from the significant increase noted for CSF glutamine concentration, since glutamine is one of the major amino-acid components of cerebral tissue (Perry et al., 1971). Its release into CSF could, therefore, account for large rises in concentration found in the present study.
In normal individuals the presence of a significant blood-CSF barrier to amino-acids is demonstrated clearly by the observation that only three out of 23 amino-acids quantitated (glutamine, phosphoserine, and phosphoethanolamine) have a CSF-plasma concentration ratio greater than 0.5 (McGale et al., 1977). Animal experiments indicate that both the choroid plexus (Lorenzo and Cutler, 1969; Franklin et al., 1975) and extrachoroidal sites (Levin et al., 1971; Dudzinski and Cutler, 1974) are involved in the active transport of amino-acids in order to maintain the normal CSF composition. It would, therefore, seem reasonable to suggest that inflammatory changes involving the meninges and choroid plexuses could cause disturbances of their transport mechanisms, in a manner similar to that previously described in relation to inorganic ions and protein in patients with meningitis (Nobecourt and Voisin, 1903; Cohen, 1927; Kabat et al., 1942; Tubiana et al., 1951; Rossi and Schneider, 1953; Taylor et al., 1954; Sambrook, 1974). Support for this view is provided in the present study by the significant increase in CSF proline and cystine concentrations in purulent meningitis, since both 
these amino-acids are excluded almost completely from CSF in normal individuals in spite of their high plasma concentrations (McGale et al., 1977). The pattern of change in individual CSF aminoacid concentrations found in the present study cannot be accounted for by a systemic disturbance of any of the transport systems known to exist in the choroid (Lorenzo, 1974).

\section{References}

Bradbury, M. W. B., Stubbs, J., Hughes, I. E., and Parker P. (1963). The distribution of potassium, sodium, chloride and urea between lumbar cerebrospinal fluid and blood serum in human subjects. Clinical Science, 25, 97-105.

Buryakova, A. V., and Sytynsky, I. A. (1975). Aminoacid composition of the cerebrospinal fluid in acute neuroinfections in children. Archives of Neurology (Chicago), 32, 28-31.

Cohen, H. (1927). The magnesium content of the cerebrospinal fluid and other body fluids. Quarterly Journal of Medicine, 20, 173-186.

Dudzinski, D. A., and Cutler, R. W. P. (1974). Spinal subarachnoid perfusion in the rat: glycine transport from the spinal fluid. Journal of Neurochemistry, 22, 355-361.

Franklin, G. M., Dudzinski, D. S., and Cutler, R. W. P. (1975). Amino-acid transport into the cerebrospinal fluid of the rat. Journal of Neurochemistry, 24, 367-372.

Holden, J. J. (1961). Amino Acids Pools, pp. 73-108. Elsevier: Amsterdam.

Houpert, Y., Tarallo, P., and Siest, G. (1976). Quantitative determination of granulocytic amino-acids in healthy men and women. Clinica Chimica Acta, 69, 383-386.

Kabat, E. A., Moore, D. H., and Landow, H. (1942). An electrophoretic study of the protein components in cerebrospinal fluid and their relationship to serum proteins. Journal of Clinical Investigation, 21, 571-577.

Lakke, J. R. W. F., and Teelken, A. W. (1976). Amino-acid abnormalities in the cerebrospinal fluid of patients with Parkinsonism and extrapyramidal disorders. Neurology (Minneapolis), 26, 489-493.

Levin, E., Nogueira, G. J., and Wright, P. M. (1971). Transfer of amino-acids and urea to and from the subarachnoid space. Journal of Physiology (London), 218, 42-43P.

Lorenzo, A. V. (1974). Amino-acid transport mechanisms of the cerebrospinal fluid. Federation Proceedings, 33, 2079-2085.

Lorenzo, A. V., and Cutler, R. W. P. (1969). Amino- acid transport by the choroid plexus in vitro. Journal of Neurochemistry, 16, 577-585.

McGale, E. H. F., Pye, I. F., Stonier, C., Hutchinson, E. C., and Aber, G. M. (1977). Studies of the interrelationship between cerebrospinal fluid and plasma amino-acid concentrations in normal individuals. Journal of Neurochemistry, 29, 291-297.

McGale, E. H. F., Pye, I. F., Corston, R., Stonier, C., Hutchinson, E. C., and Aber, G. M. (1979). The effect of haemodialysis on cerebrospinal fluid and plasma amino-acids. Clinical Chimica Acta, 92, 73-80.

Mutain, R., Monaco, F., Durelli, L., and Delsediume, M. (1974). The free amino-acids in the cerebrospinal fluid of epileptic subjects. Epilepsia, 15, 593597.

Nobecourt, P., and Voisin, R. (1903). Les chlorures du liquide cephalorachidien. Archives Générales de Medecine, 192, 3018-3025.

Perry, 'T. L., Hansen, S., Berry, K., Mok, C., and Lesk, D. (1971). Free amino-acids and related compounds in biopsies of human brain. Journal of Neurochemistry, 18, 521-528.

Perry, T. L., Hansen, S., Lesk, D., and Kloster, M. (1973). Amino-acids in plasma, cerebrospinal fluid and brain of patients with Huntington's chorea. Advances in Neurology, 1, 603-618.

Pye, I. F., Stonier, C., and McGale, E. H. F. (1978), Double-enzymatic assay for determinations of glutamine and glutamic acid in cerebrospinal fluid and plasma. Analytical Chemistry, 50, 951-953.

Pye, I. F., McGale, E. H. F., Stonier, C., Hutchinson, E. C., and Aber, G. M. (1979). Studies on cerebrospinal fluid and plasma amino-acids in patients with steady-state chronic renal failure. Clinica Chimica Acta, 92, 65-72.

Rossi, G., and Schneider, G. (1953). Electrophoretische untersuchung von pathologischen liquor cerebropinalis. Klinische Wochenschrift, 31, 969-975.

Sambrook, M. A. (1974). The relationship between cerebrospinal fluid and plasma electrolytes in patients with meningitis. Journal of the Neurological Sciences, 23, 265-273.

Stern, J. R., Eggleston, L. V., Hams, R., and Krebs, M. A. (1949). Accumulation of glutamic acid in isolated brain tissue. Biochemical Journal, 44, 410418.

Taylor, L. M., Smith, H. J., and Hunter, G. (1954). Blood-CSF barrier to bromide in diagnosis of tuberculous meningitis. Lancet, 1, 700-702.

Tubiana, M., Benda, P., and Constans, J. (1951). Sodium radio-actif ${ }^{24} \mathrm{Na}$ et liquide céphalo-rachidiene; applications au diagnostic des méningites tuberculeuses et des compressions médullaires. Revue Neurologique, 85, 17-35. 